\title{
New specialty potato varieties give farmers growing and marketing options
}

\author{
Ron Voss $\square$ Herb Phillips $\square$ Kent Brittan $\square$ Harry Carison $\square$ \\ Manuel Jimenez $\square$ Don Kirby $\square$ Richard Molinar $\square$ Joe Nunez \\ Jesus Valencia $\square$ Garth Veerkamp \\ Nancy Garrison $\quad$ Mark Gaskell \\ 口 Richard Smith
}

\begin{abstract}
California's small-scale farmers and direct marketers lead the nation in production of specialty potatoes, primarily yellow-fleshed
\end{abstract} types. Currently, limited varieties are available to meet the requirements for direct-marketing, organic production and perceived high consumer quality parameters such as flavor. During the 1990s, UC Davis and UC Cooperative Extension collaborated with farmers throughout California to conduct trials to identify the most desirable or profitable varieties among existing and potential new specialty potato varieties. Many European varieties are superior in yield and may be equal in quality to standard varieties. Specialty potato varieties with a diversity of yield potential, tuber size distribution, maturity and flesh-color intensity are available for conventional or alternative production and marketing systems. Consumer evaluations indicate variable preferences for color, taste, texture and other quality parameters. No general conclusions can be made about consumer preference for varieties.

Potato consumption in the United States has increased slowly but steadily during the past two decades, primarily because of the increased role of fast-food restaurants and the prominence of french fries and potato bars (Middaugh 1999). Other reasons for this increase in popularity and consumption of potatoes include awareness by increasingly health-conscious American consumers that potatoes have no fat or cholesterol, are high in easily digestible carbohydrates and are high in vitamins and minerals. The use of microwave ovens for quick and easy preparation in the 1980 s reintroduced the "baked" potato into home cooking. The trend for upscale restaurants to highlight new, whole red potatoes, then yellow-fleshed potatoes, and more recently mashed potatoes, particularly mashed yellow-fleshed potatoes, has helped to keep potatoes in the forefront of the American diet (Gunther 1992).

Successful small-scale farmers depend on production and marketing diversity for economic stability. Important production diversity components include organic production systems and specialty crops. Marketing diversity is achieved via numerous directmarket outlets. Small farmers depend heavily on organically grown or newly harvested fresh potato tubers of varieties that direct-market customers prefer. These are generally specialty varieties not typically grown by conventional large-scale producers and not commonly found in supermarkets.

In recent years, the demand for specialty potatoes has increased. Seed production statistics as well as subjective observations by farmers' market managers and Cooperative Extension advisors indicate a steady increase during the past 5 years in the number of farmers and acreage of production of specialty potatoes (Middaugh 1999).
Most of this increase has been in yellowfleshed potatoes, although some increase has been in fingerlings and in exotics, such as purple skin and flesh, red flesh, and multicolored skin and/ or flesh. The increased demand has resulted partly from proactive marketing by small farmers toward established consumers, and partly from consumers demanding yellow-fleshed potatoes. Interest in and knowledge about potatoes has increased among consumers. Varieties grown and consumed in much of South America (the native home of potatoes) and Europe have much more diversity, tend to be yellow fleshed, and are generally considered to have more natural flavor (Walker 1996).

California is the leader and trendsetter in specialty crop production and marketing in the United States. Many specialty crop marketing companies are located in California, and most specialty crop imports enter through the state (Thoman 1998). Consumption of many specialty crops is highest in California, and specialty potatoes are no exception. The demand for seed of yellow-fleshed and other specialty potatoes by California growers exceeds that of any other state (Middaugh 1999).

The majority of California specialty potato acreage is planted to the Yukon Gold variety, which was developed and released in Ontario, Canada, in the 1980s. In 1990, Yukon Gold ranked 25th among the most popular varieties in the United States. In 1997, it ranked 12th. In California, the most popular varieties grown by small-scale produc- 


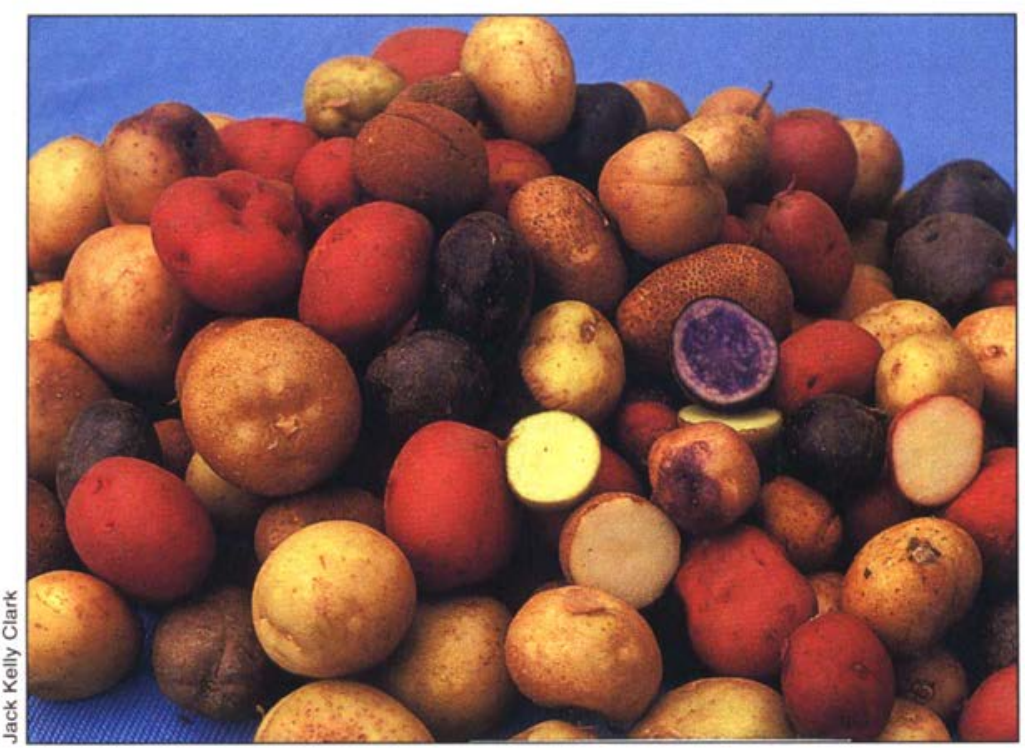

$\Delta$ Specialty potatoes offer a variety of skin colors, flesh colors, sizes, flavors and textures.

ers are Yellow Finn and Bintje, both very old European varieties that are no longer protected and therefore are not subject to royalties (Middaugh 1999). Bintje, like the American variety Russet Burbank, has excellent quality, but it is difficult to grow and has a low percentage of No. 1 tubers. Still a prominent variety in Europe, Bintje commands a smaller percentage of the annual market than it used to. The Yellow Finn has good culinary quality, but has relatively low yield potential and is susceptible to diseases and storage decay. It is rarely grown in Europe. Therefore the need exists for improved yellow-fleshed potato varieties, from both consumer and producer perspectives.

\section{Variety improvement trials}

In the late 1980 s, we planted variety trials to compare new and improved specialty potatoes. With the 1995 change in the U.S. Plant Variety Protection Act, private European breeding companies began entering new varieties into our trials. Currently, one German and four Dutch companies have entries in UC trials. In 1996, the USDA western regional potato variety program added specialty potatoes as a varietal category for multistate evaluation, an indication of the growing interest in these varieties. Most of the evaluation has concentrated on production parameters - yield, size, visual quality, storability and disease susceptibility. Some consumer and culinary evaluations have also been conducted.

Production evaluation. Table 1 summarizes the production performance of nine of the most commonly tested yellow-fleshed varieties in trials from 1988 to 1998 . The locations of these trials included conventional high-input sites; organic high-input sites; and organic low-input sites. They were located in Kern, Siskiyou, Modoc, Placer, Nevada, San Benito, Stanislaus, Fresno, Monterey and Santa Barbara counties. Entries ranged from Yukon Gold (the standard yellowfleshed potato in conventional production and marketing) in 23 trials, to Agria (a new, protected variety from the Netherlands) in 6 trials. No statistically significant site $\times$ variety interaction occurred for total or marketable yield, vine vigor or maturity, tuber visual rating, or skin or flesh color. Thus relative production was consistent among the different locations. For this reason, the data for all locations is combined and averaged in table 1.
A Ron Voss shows that the internal flesh of a potato variety may be colored.

Agria had twice the average total yield of G742-4X, a new variety from Canada. Yellow Finn, one of the standards in alternative production and marketing systems, was among the lowest in total yield, with a high percentage of small tubers. In conventional markets, the large tubers commonly command a higher price; in alternative markets, the smaller tubers commonly cost more. The varieties with the highest percentage of large tubers were Agria, Rose Gold, Red Gold and G742-4X. The varieties with the highest percentage of small tubers were Bintje, Granola, German Butter Ball and Yellow Finn. Tuber flesh intensity ranged from dark yellow (for example, German Butter Ball, Yellow Finn and Agria) to light yellow (for example, Bintje, G742-4X and Rose Gold). From this study, it was not possible to determine if some varieties perform better than others in low-input or organic systems, while others might 

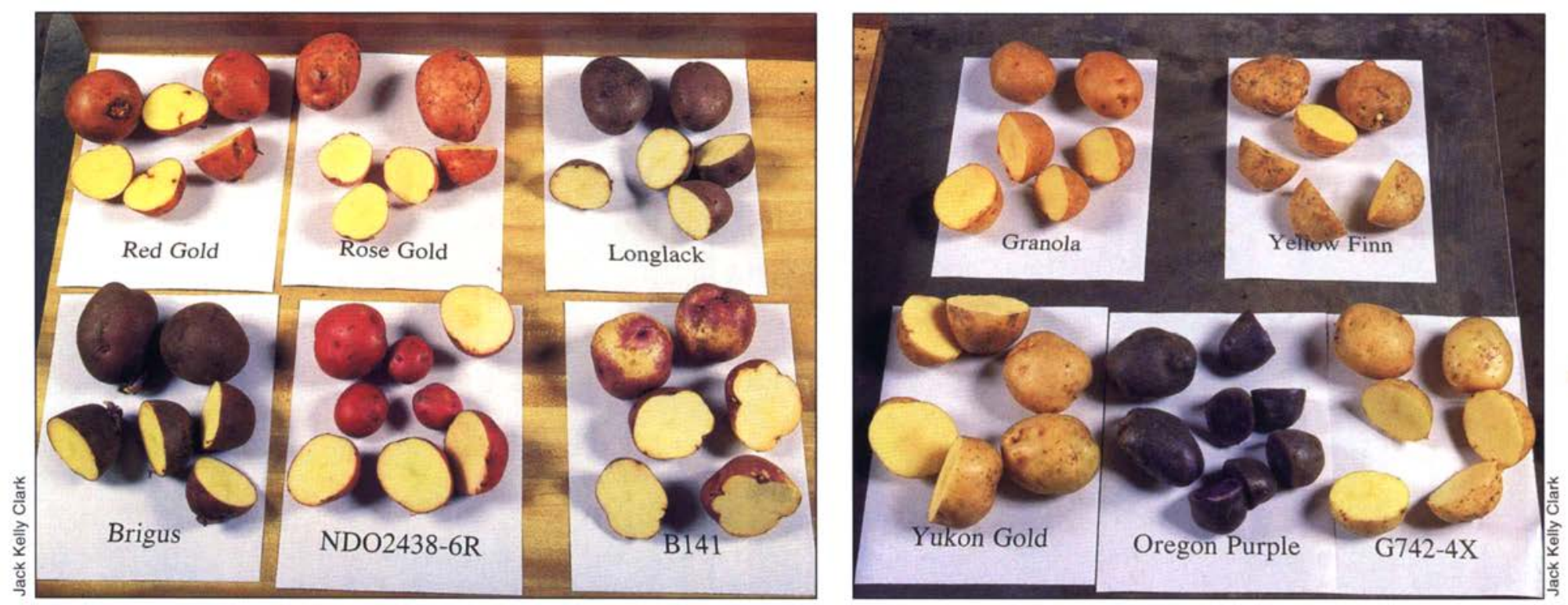

Consumers in Placer and Santa Clara counties showed a wide range of preferences for taste, texture and appearance among potato varieties.

perform better in high-input and conventional systems.

Consumer evaluation. We collected consumer evaluation data on 17 varieties from 75 master gardeners in Santa Clara County in 1990 and 1991 (table 2). Tubers were all grown at one location in each year, but at different locations in 1990 and 1991. We did not collect yield data at either location. The tubers were boiled, baked or steamed, depending on the recommendation of the seed source. The consumer evaluations were based primarily on consumers' perception of taste.

We had 100 consumers evaluate 13 potato varieties at a Placer County Farmers' Market in 1997 (table 3). The tubers were baked and cooled before evaluation. At Placer County, these evaluations were based on consumers' perception of taste, appearance and texture. Similar rating sheets were used for all consumer evaluations. Consumers were asked to evaluate each variety on a scale of 1 to 10 , with 1 being "terrible" and 10 being "wonderful" or "heavenly." Participants were invited to make brief comments on each variety.

Additional evaluations were conducted in Santa Clara County, but the data is not included here because the set of varieties evaluated contained only approximately half of those evaluated by the master gardeners. Results of those common varieties were essen- tially identical to those in the previous evaluation (unpublished data).

These consumer evaluation data illustrate a common finding in all test samples of consumers: perceived quality varies according to individual consumer preference, and thus is not only subjective but highly variable. For example, many consumers perceived a particular variety, grown at the same location in the same year, as mealy, while others perceived it as moist.

Most varieties received the extreme ratings of 1 and 10 overall scores. The average evaluation ranged from 5.8 to 6.8 at Santa Clara, and from 5.2 to 7.5 at Placer. The standard deviations for each variety were similar and high at both locations (1.9 to 2.4 ), indicating a

TABLE 1. Performance of yellow-fleshed potatoes in locations throughout California, 1988-1998

\begin{tabular}{|c|c|c|c|c|c|c|c|c|c|c|}
\hline \multirow[b]{2}{*}{ Variety } & \multirow{2}{*}{$\begin{array}{l}\text { No. of } \\
\text { trials }\end{array}$} & \multirow{2}{*}{$\begin{array}{l}\text { Total } \\
\text { yield }\end{array}$} & \multicolumn{3}{|c|}{ Yield } & \multirow{2}{*}{$\begin{array}{l}\text { Vine } \\
\text { vigor* }^{*}\end{array}$} & \multirow{2}{*}{$\begin{array}{c}\text { Vine } \\
\text { maturityt }\end{array}$} & \multirow{2}{*}{$\begin{array}{c}\text { Visual } \\
\text { appearance }\end{array}$} & \multirow{2}{*}{$\begin{array}{l}\text { Skin } \\
\text { color }\end{array}$} & \multirow{2}{*}{$\begin{array}{c}\text { Flesh } \\
\text { intensity§ }\end{array}$} \\
\hline & & & Marketable & Large & Small & & & & & \\
\hline & & cwt/ac & ........... & $\%$ of tota & .......... & & & & & \\
\hline Agria & 6 & 440 & 86 & 44 & 42 & 4.6 & 4.6 & 3.7 & Yellow & 3.4 \\
\hline Bintje & 4 & 405 & 86 & 10 & 77 & 3.8 & 3.9 & 2.7 & Yellow & 2.3 \\
\hline G742-4X & 15 & 220 & 89 & 39 & 52 & 2.6 & 1.8 & 3.5 & Yellow & 2.3 \\
\hline German Butter Ball & 11 & 405 & 91 & 22 & 69 & 4.5 & 4.4 & 3.0 & Yellow & 3.6 \\
\hline Granola & 13 & 360 & 92 & 24 & 68 & 4.2 & 3.8 & 3.5 & Yellow & 2.7 \\
\hline Red Gold & 7 & 405 & 95 & 56 & 38 & 3.0 & 1.7 & 2.8 & Red & 2.4 \\
\hline Rose Gold & 18 & 350 & 90 & 56 & 34 & 3.7 & 2.9 & 2.9 & Pink & 2.3 \\
\hline Yellow Finn & 17 & 255 & 82 & 25 & 57 & 3.8 & 3.6 & 3.0 & Yellow & 3.5 \\
\hline Yukon Gold & 23 & 305 & 93 & 61 & 30 & 3.4 & 2.0 & 3.6 & Yellow & 3.3 \\
\hline Average & - & 325 & 91 & 42 & 49 & 3.6 & 2.9 & 3.2 & - & 2.8 \\
\hline LSD $(.05)$ & - & 135 & ns & 13 & 15 & 0.7 & 0.6 & 0.6 & - & 0.6 \\
\hline
\end{tabular}

5 = Largest, $1=$ Smallest

$+5=$ Latest, $1=$ Earliest

$\ddagger 5$ = Excellent, 1 = Poor

$\S 5=$ Darkest yellow, $1=$ White 
similar distribution of evaluation scores among both sets of consumers. Yellow-fleshed and whitefleshed varieties had similar ratings at both locations. Yellow-skinned and red-skinned varieties also had similar ratings at both locations. At Placer County, the purple-skinned varieties were given significantly lower ratings; at Santa Clara, the difference was not significant.

When comparing groups of varieties based on skin or flesh color, no differences existed among the consumer preferences for these groups of potato varieties at either of the locations, except for the somewhat lower preference for purple-skinned varieties. However, to individual consumers, perceived differences obviously existed. While the preference and demand for yellow-fleshed varieties may be increasing, the attractiveness of redskinned varieties is strong, at least among these consumer groups (farmers' markets and home gardeners). Many small organic farmers prefer Yellow Finn to Yukon Gold, partly because they perceive the culinary qualities to be superior. These consumer taste tests suggest no significant difference between the two.

These results are similar to those reported from a 1996 potato tasting at Pike Place Market in Seattle, conducted by Washington State University (Sorensen and Evans 1997). In this study, consumers rated seven varieties on a scale of 1 to 5 (very poor to excellent) for three separate characteristics: flavor, texture and appearance. All tubers had been boiled. Approximately 350 market visitors rated the seven varieties. As in the California studies, all varieties received the extreme ratings in all three culinary categories. Statistical significance values were not reported, but of the three varieties common to the California tasting evaluations, Yukon Gold ranked higher than Yellow Finn in all categories, with All Blue intermediate between them.

The characteristics of numerous other available specialty varieties are reported in annual summaries pub- lished jointly by UC Davis and the California Potato Research Advisory Board. Many of the trials included observational data only, with only subjective data reported (Voss et al. 1999).

\section{Many desirable new varieties}

Many new yellow-fleshed varieties are available as a result of increased emphasis on specialty variety development in the United States and the change in plant variety protection laws, which now allow privately owned European varieties to be marketed here. Many of these new varieties, such as Agria, German Butter Ball and Red Gold, are superior in yield and may be equal in quality to the existing standard varieties. The two most commonly grown yellow-fleshed varieties, Yukon Gold and Yellow Finn, were rated equally in consumer

TABLE 2. Tasting evaluation - Santa Clara County Master Gardeners, 1990 and 1991

\begin{tabular}{|c|c|c|c|c|c|}
\hline Variety & $\begin{array}{l}\text { Skin } \\
\text { color }\end{array}$ & $\begin{array}{l}\text { Flesh } \\
\text { color }\end{array}$ & $\begin{array}{c}\text { Range } \\
\text { in scores* }\end{array}$ & $\begin{array}{l}\text { Average } \\
\text { score }^{*}\end{array}$ & $\begin{array}{l}\text { Frequent } \\
\text { comments }\end{array}$ \\
\hline All Blue & Purple & Blue & $1-9$ & 5.8 at & Mealy, unusual, mild \\
\hline Augsburg Gold & Yellow & Yellow & $2-10$ & $6.6 \mathrm{ab}$ & Waxy, smooth \\
\hline Bintje & Yellow & Yellow & $2-10$ & $6.1 \mathrm{ab}$ & Mealy, mild \\
\hline Bison creamy & Red & White & $2-10$ & $6.6 \mathrm{ab}$ & Moist, good flavor, \\
\hline Caribe & Red & White & $3-10$ & $6.8 \mathrm{~b}$ & Moist, sweet, firm \\
\hline Desiree & Pink & Yellow & $2-10$ & $6.4 \mathrm{ab}$ & Bland, dry, moist, firm \\
\hline German Yellow & Yellow & Yellow & $1-10$ & $6.4 \mathrm{ab}$ & Smooth, sweet \\
\hline Green Mountain & White & White & $3-10$ & $6.7 \mathrm{~b}$ & $\begin{array}{l}\text { Dry, good texture, } \\
\text { bland }\end{array}$ \\
\hline Katahdin & White & White & $1-10$ & $6.2 \mathrm{ab}$ & Waxy, bland \\
\hline Norgold Russet & Rust & White & $1-10$ & $6.5 \mathrm{ab}$ & Mealy, moist, smooth \\
\hline Pink Pearl & Pink & White & $1-10$ & $6.7 \mathrm{~b}$ & Moist, soft, bland \\
\hline Purple Chief & Purple & White & $2-10$ & $6.5 \mathrm{ab}$ & Mealy, bland \\
\hline Red Dale & Red & White & $1-10$ & $6.0 \mathrm{ab}$ & Moist, creamy, bland \\
\hline Rose Finn Apple & Pink & Yellow & $3-10$ & $6.4 \mathrm{ab}$ & Waxy, mellow \\
\hline Sangre & Red & White & $2-10$ & $6.3 \mathrm{ab}$ & Moist, mild \\
\hline Yellow Finn & Yellow & Yellow & $3-10$ & $6.7 \mathrm{~b}$ & Moist, creamy, mild \\
\hline Yukon Gold & Yellow & Yellow & $2-10$ & $6.5 \mathrm{ab}$ & Mealy, mild \\
\hline \multicolumn{2}{|c|}{ Average score of 7 yellow fleshed } & $6.4 \mathrm{~ns}$ & & & \\
\hline \multicolumn{2}{|c|}{ Average score of 9 white fleshed } & $6.5 \mathrm{~ns}$ & & & \\
\hline \multicolumn{2}{|c|}{ Average score of 5 yellow skinned } & $6.5 \mathrm{~ns}$ & & & \\
\hline \multicolumn{2}{|c|}{ Average score of 7 red or pink skinned } & $6.5 \mathrm{~ns}$ & & & \\
\hline \multicolumn{2}{|c|}{ Average score of 2 purple skinned } & $6.2 \mathrm{~ns}$ & & & \\
\hline
\end{tabular}

"75 Evaluations; 10 = "Heavenly," 1 = "Terrible," based on taste

†Scores followed by the same letter are not significantly different at $5 \%$ level

TABLE 3. Tasting evaluation - Placer County Farmers' Market, 1997

\begin{tabular}{|c|c|c|c|c|c|}
\hline Variety & $\begin{array}{l}\text { Skin } \\
\text { color }\end{array}$ & $\begin{array}{l}\text { Flesh } \\
\text { color }\end{array}$ & $\begin{array}{c}\text { Range } \\
\text { in scores* }\end{array}$ & $\begin{array}{c}\text { Average } \\
\text { score }\end{array}$ & $\begin{array}{l}\text { Frequent } \\
\text { comments }\end{array}$ \\
\hline A83359-5R & Red & White & $1-10$ & 6.7 det & Bitter, good flavor, moist \\
\hline AD82706-2R & Red & White & $1-10$ & $7.5 \mathrm{e}$ & Good flavor, sweet, mois \\
\hline All Blue & Purple & Blue & $1-10$ & $6.0 \mathrm{abcd}$ & Ugly color, good color \\
\hline B141 & Wht/Pur & White & $1-10$ & $5.4 \mathrm{ab}$ & Dry \\
\hline Delta Gold & Yellow & Yellow & $2-10$ & $5.8 \mathrm{abcd}$ & Good color, dry \\
\hline Desiree & Pink & Yellow & $1-10$ & 5.8 abcd & Good flavor, firm \\
\hline Fontenot & Red & White & $1-10$ & $5.6 \mathrm{abc}$ & Dry, good flavor \\
\hline G742-4X & Yellow & Yellow & $1-10$ & $6.3 \mathrm{bcd}$ & Good flavor, moist \\
\hline Longlac & Purple & White & $1-10$ & $5.2 \mathrm{a}$ & Dry, firm, strange texture \\
\hline Red LaSoda & Red & White & $2-10$ & 6.6 cde & $\begin{array}{l}\text { Dry, moist, good flavor, } \\
\text { poor taste }\end{array}$ \\
\hline Rose Gold & Pink & Yellow & $1-10$ & $6.3 \mathrm{bcd}$ & $\begin{array}{l}\text { Good flavor, smooth, } \\
\text { creamy }\end{array}$ \\
\hline Ruby Red & Red & White & $1-10$ & $6.8 \mathrm{de}$ & Good flavor, moist \\
\hline Yellow Finn & Yellow & Yellow & $2-10$ & $6.4 \mathrm{bcd}$ & Good flavor, sweet \\
\hline Yukon Gold & Yellow & Yellow & $1-10$ & $6.4 \mathrm{bcd}$ & Firm \\
\hline \multirow{5}{*}{\multicolumn{2}{|c|}{$\begin{array}{l}\text { Average of } 6 \text { yellow fleshed } \\
\text { Average of } 7 \text { white fleshed } \\
\text { Average of } 4 \text { yellow skinned } \\
\text { Average of } 7 \text { red or pink skinned } \\
\text { Average of } 3 \text { purple skinned }\end{array}$}} & \multicolumn{2}{|c|}{$6.2 \mathrm{~ns}$} & & \\
\hline & & \multicolumn{2}{|c|}{$6.3 \mathrm{~ns}$} & & \\
\hline & & \multicolumn{2}{|c|}{$6.2 \mathrm{ab}$} & & \\
\hline & & \multicolumn{2}{|c|}{$6.5 \mathrm{~b}$} & & \\
\hline & & \multicolumn{2}{|c|}{$5.5 \mathrm{a}$} & & \\
\hline
\end{tabular}

-100 evaluations; 10 = "Wonderful," 1 = "Terrible," based on taste, appearance, texture

†Scores followed by the same letter are not significantly different at $5 \%$ level; $\mathrm{ns}=\mathrm{no}$ significant difference. 
evaluations. Yellow Finn has a higher percentage of small tubers than Yukon Gold and thus different market targets. Consumer evaluations indicate a wide range in preferences among individual varieties as to taste, appearance and texture. However, no consensus of general preferences exists as to skin color or flesh color.

R. Voss is Extension Vegetable Specialist, Department of Vegetable Crops, UC Davis; H. Phillips is Staff Research Associate, Department of Vegetable Crops, UC Davis; K. Brittan is Farm Advisor, UCCE Sacramento County; Harry Carlson is Farm Advisor, Siskiyou and Modoc Counties and Superintendent, Intermountain Research and Extension Center; N. Garrison is Horticultural Advisor, UCCE Santa Clara County; M. Gaskell is Farm Advisor, UCCE Santa Barbara and San Luis Obispo Counties; M. Jimenez is Farm Advisor, UCCE Tulare County; D. Kirby is Staff Research Associate, Intermountain Research and Extension Center; $R$.

Molinar is Farm Advisor, UCCE Fresno County; J. Nunez is Farm Advisor, UCCE Kern County; R. Smith is Farm Advisor, UCCE Monterey County; J. Valencia is Farm Advisor, UCCE Stanislaus County; and G. Veerkamp is Farm Advisor, UCCE Placer-Nevada Counties.

\section{References}

Gunther J. 1992. The demand of potatoes in 1995. In: Proceedings, University of Idaho Winter Commodity School. Twin Falls: University of Idaho. Vol 23, p 266-72.

Middaugh AR. 1999. 1998 Potato Statistical Yearbook. Englewood, CO: National Potato Council. $96 \mathrm{p}$.

Sorensen E, Evans S. 1997. Comparative Tasting of Potatoes at the "Taste of Washington Farm." Washington State University Cooperative Extension Report. $4 \mathrm{p}$.

Thoman D (Ed). 1998. The Packer-1998 Produce Availability \& Merchandising Guide. Vol CIV(54). Lenexa, KS: Vance Publishing Corp. 520 p.

Voss RE, Phillips $\mathrm{H}$, Carlson $\mathrm{H}$, et al. 1999. Potato Variety Selection and Development, 1998 Annual Report. Vegetable Crops Department Special Publication. University of California, Davis. $60 \mathrm{p}$.

Walker TJ. 1996. Patterns and Implications of Varietal Changes in Potatoes. International Potato Center Working Paper, Series No. 1994-3. Lima, Peru: International Potato Center. 54 p.

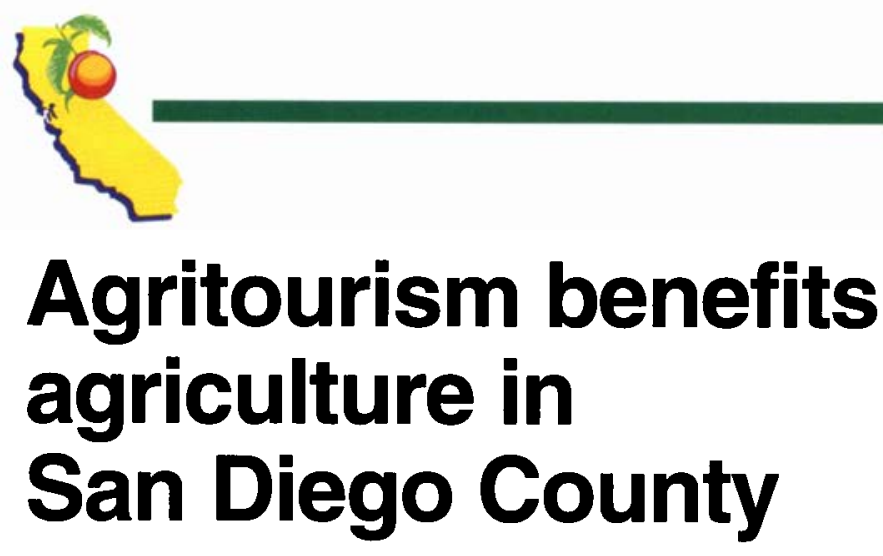
Ramiro E. Lobo - George E. Goldman
口 Desmond A. Jolly
B. Diane Wallace $\square$ Wayne L. Schrader $\square$ Scott A. Parker

Marketing agritourism as a separate segment of the tourism industry could have substantial benefits for local agriculture.

Agritourism is defined as any business conducted by a farmer for the enjoyment or education of the public, to promote the products of the farm and to generate additional farm income (Hilchey 1993). It includes a variety of facilities and activities that are increasingly available in San Diego County, such as agricultural festivals, farm visits, farm tours, demonstration farms, farm stays, wineries, nursery trails and agricultural museums. In addition, there are more than 20 Certified Farmers' Markets that operate in most incorporated communities of the county. Combining the large tourism industry with the uniqueness and diversity of local agriculture may offer a whole new set of opportunities for farmers to diversify their operations and their revenue sources.

The potential benefits of agritourism for local agriculture are varied. First, agritourism may generate diversification opportunities for local farmers to increase revenues and enhance the viability of their operations. Second, it may be an excellent tool to educate the public about the importance of agriculture and its contribution to the county's economy and quality of life. Third, it may provide economic incentives and reduce friction in the agricultural-urban interface, thus helping to preserve agricultural land in San Diego County. Finally, agritourism may enhance the appeal and demand for local products, 